\title{
The Slavic Collection at the University of Iowa
}

\author{
T A T J A N A L ORKOVIC
}

Russian language studies at The University of Iowa appeared during the 1944-1945 school year under the auspices of the Department of Romance Languages. The course was dropped for a time, but reappeared for the 1947-1948 term as a one-year course. The program expanded in 1953 to a two-year course, under the direction of Professor Alexandre Aspel.

The Department of Russian within the College of Liberal Arts was established under the leadership of Professor Max Oppenheimer, Jr., in 1961. From that point, Russian language and literature studies were firmly established at The University of Iowa. The undergraduate major in Russian was created in 1962 and, in 1965, following widespread and growing interest in Russian studies, the Master of Arts degree was established.

The teaching of Russian and Soviet history and political science courses at The University of Iowa is longstanding. Russian history courses have been a part of the departmental offerings since 1943 and the Department of Political Science has offered courses in Russian and Soviet foreign relations and government since 1949.

The Slavic collection of the University Libraries was begun as a support to the establishment of the Russian Department and to the teaching of Russian and Soviet history and political science. Helene Scriabine, the pioneer and promoter of Russian studies at The University of Iowa, has vividly described her first visit to the Library, where there were no Russian books on the shelves. ${ }^{1}$ She became concerned because she could not imagine being a successful teacher without a collection of

\footnotetext{
${ }^{1}$ Helene Scriabine taught Russian language and literature at The University of Iowa in the 1960s and 1970s. She is most famous for her memoirs, Siege and Survival: The Odyssey of a Leningrader (1973), After Leningrad: From the Caucasus to the Rhine, August 9, 1942-March 25, 1945: A Diary of Survival During World War II (1978), The Allies on the Rhine, 1945-1950 (1980), and Coming of Age in the Russian Revolution: The Soviet Union at War (1985).
} 
Russian materials in the Library to support her teaching. She visited the then head of the acquisitions department, the late Frank Hanlin, and asked him for help. Mr. Hanlin, an outstanding bookman, understood Helene Scriabine's concerns and offered her full library support. In search of Russian books, Helene Scriabine found a Russian language and literature collection for sale at a Russian antiquarian book store in New York. The antiquarian's name was Vasil'ev, but the store does not exist any more. Frank Hanlin agreed to buy the collection of approximately 5000 volumes, and that gathering became the base of the Slavic collection at The University of Iowa. In the fiscal year 1964-1965 Hanlin established the first regular Russian line within the University Libraries' acquisitions budget. Funds allocated to the Slavic collection fluctuated through the years reflecting the University's ups and downs. The average yearly expenditures for the years 1964 through 1978 were $\$ 8,543$, and for the years 1979 through 1988 expenditures averaged $\$ 10,564$.

The first Slavic librarian, Mr. Vasyl Luchkiw, joined the Library staff on July 1, 1962. Mr. Luchkiw was Ukrainian in background and during his tenure the Library experienced a modest growth of Ukraniana in its collections, in addition to the steady acquisitions and processing of Russian materials. Mr. Luchkiw left The University of Iowa Libraries in October of 1966.

I was the next Slavic librarian, appointed on January 1, 1968. Although I was hired as a Slavic cataloger within the cataloging department, I also served as an area studies specialist. My responsibilities were to select materials for the Slavic collection, to provide a full reference service in my area of expertise, and to process all book and non-book materials pertaining to Slavic area studies, with the exception of serials. The only help that I could count on was from students who held part-time jobs in the Library. We trained the students to apply their knowledge of Slavic languages to the different paraprofessional activities in technical services. By learning how to use Slavic library re- 
sources all of these students increased their skills and some of them even developed an interest in librarianship.

Because the emphasis in teaching at The University of Iowa was on Russian language and literature and Russian and Soviet social sciences, I had to limit my collection development efforts to these areas. I believed, however, that a good Russian and Soviet collection had to be surrounded by adequate collections of related Slavic materials. Modestly and slowly, within the constraints of the Russian budget allocations, we collected basic materials in Old Church Slavonic, Polish, Czech, SerboCroatian, and other Slavic languages. Throughout the years a broader Slavic collection has grown around its Russian core. We were also able to build a strong Slavic reference collection.

In the Spring of 1989 we conducted a shelf list count of the Slavic collections at The University of Iowa Libraries applying a technique used at the University of California at Berkeley. ${ }^{2}$ The process involves using the Library of Congress classification schedules. These schedules group all of human knowledge into categories along with alphanumeric symbols, such as PG20013987 for Russian language and literature. An inventory was compiled of all the possible classes and subclasses in the schedules involving the Slavic world. This inventory was then compared to the "shelf list," a catalog of books in the order in which they stand on the shelves according to the Library of Congress classsification schedules. The result was a count of the titles of books about the Soviet Union and Eastern Europe in all languages. These counts were possible in those parts of the Library of Congress classification which lent themselves to the area approach, namely to those classes and subclasses which are arranged by country and language. The count result is an approximate number of titles owned by The University of Iowa Libraries.

As of 1989, the Slavic area studies collection was represented by 39,924 titles. The University of Iowa Libraries owned 14,451

\footnotetext{
${ }^{2}$ LeRoy D. Ortopan, Analysis of Slavic and East European materials at the University of California, Berkeley (Berkeley: General Library, University of California, 1984)
} 
titles in Russian language and literature, along with 3,759 titles in other Slavic and East European languages and literatures. The overall Russian and Slavic languages and literatures collection contained 18,210 titles, or $46 \%$ of the total count in the Slavic area studies collection. Furthermore, within the Russian and Slavic languages and literature collection we counted titles written in vernacular languages and others written in Western European languages. We found the following ratio: Of 18,210 titles in the collection, 5,883 were written in Western European languages, or $32 \%$ of the total. The remaining 12,327 titles in Slavic vernacular languages, or $68 \%$ of the total languages and literature collection, attest to the strength of the Slavic language materials collection at The University of Iowa. The Russian, Soviet and other Slavic and Eastern European history holdings were represented by 11,226 titles, for $28 \%$ of the total count.

The Library had 346 current serials subscriptions in Slavic and East European languages, of which 240 titles were in Russian or were translated into English from Russian. The Government Publications librarians reported that they held approximately 3,000 titles pertaining to the Soviet Union and Eastern Europe. The largest group of materials not represented in the Library of Congress classification can be found on microfilm, microfiche, and microcards. These holdings were placed at 10,000 titles. By adding all of these categories the approximate count of Slavic area titles at The University of Iowa Libraries was placed at 54,470 titles.

Today, the collection can support the current teaching of Russian literature, language, and folklore at the Bachelor's and Master's degree levels, as well as graduate study in Soviet history, political science, and comparative literature. 